\title{
83. 一酸化炭素中毒における耳神経学的所見補遺
}

\author{
牧嶋和見・吉田雅文・野上兼一郎（九大）
}

目的 近時, 一酸化炭素中毒に係る医法学的関心が 一層強くなりつつある。一酸化炭素中毒にともなう耳 神経学的症状の発現には,一酸化炭素ガスの暴露時間, 濃度, 吸入量, 局所の酸素要求度などが関与している と考えられる。本報告では，一酸化炭素中毒症例にお ける耳神経学的所見の解析により，この種の病態の解 明を試みた。

方法 炭塵爆発による被災者のうち急性一酸化炭素 中毒患者と，その被災25年後の一酸化炭素中毒陳旧症 例について, 各種の聴覚検査ならびに平衡機能検査を 施行しそその結果の解析を行った。

成績 急性一酸化炭素中毒患者15名の年齢は, 24〜50（平均 34．3）葴で, 被災後 5 96（平均 20.4） 時間の意識消失があった。純音聴力検查では，軽度の 感音性難聴を示す傾向があり,リクルートメントはし ばしば陰性であった。語音聴力検查では，多くの症例 で正常所見を示したが，2症例で高度の弁別能低下を 認めた。平衡機能検查ては，検查症例中の約半数に自 発眼振, 頭位眼振と, 温度眼振に扔ける眼振方向優位 性があった。一酸化炭素中毒陳旧症例では，多彩な大 脳精神病理学的所見を認めた。これらの症例のうち代 表症例として62歳男性について述べる, 痴呆と視覚 失認があった，純音聴力検查では，軽度の感音性難聴 を示し, SISI は 1 と $4 \mathrm{kHz}$ で $0 \%$, 語音弁別能は右耳 $85 \%$, 左耳 $95 \%$ であった. Bekesy とSR 検査には, 著 変を認めなかった。聴性脳幹反忘では，クリック刺戟 で各波の分㒕が不良で，潜時延長の傾向があった。中 間反応では, Özdamar \& KrausのII 型を示した。 平 衡機能検查では, 自発眼振はなく, 方向交代性頭位眼 振を認めた。温度眼振に異常なく, Romberg 陽性であ った，PETでは，広範に脳血流量 (CBF) と脳酸䒺消 費量 $\left(\mathrm{CMRO}_{2}\right)$ の低下があり，その傾向はとくに両側
側頭後頭頭頂葉で著明であった。

考察 一酸化炭素中毒における低酸素症は, 主とし て負血性低酸素症であるが，中毒に到る過程てしじし ば停滞性ならびに組織中䓯性低酸素症を伴う。したが って，それぞれの低酸素症における組織の選択的脆弱 性による病態が考えられる，本症例と同時に被災し， 他病死した剖検症例に扔ける検索と，急性一酸化炭素 中毒モデル動物における所見は，内耳レベルに著変が ないことを証明している ${ }^{132)}$. 上述の先の成績と本症例 の結果より考察すると，一酸化炭菜中毒による負血性 低酸素症などの際に，内耳とその中枢伝導路は比較的 抵抗性があり，形態学的変化も少ないと言える。急性 期における機能の低下は，脳における神経伝達物質な ど一過性の化学的変化であるうと考える。

文献

1) 牧嶋和見：日耳鼻 $75: 1225 ， 1972$.

2) Makishima $K$ et al : Tr Am Acad Ophth Otol 84: ORL 452, 1977.

質問 村井和夫(岩手医大)，1）初診時純音オージオグ

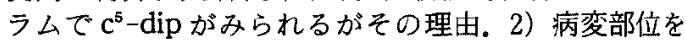
どこと推察したか，およびその理由について。応 答 1) 純音聴力検査での $c^{5}$-dip は，環境騒音の影響 であろう．2）内耳には著変がない，中枢器には，軽度 のびまん性病変の可能性がある。質問 田中康夫 (獨協医大). 形態学的には，淡蒼球や小脳にのみ変化 があり末梢には異常は認めなかったのに，ABRでは I 波の潜時も延長したのは如何に解釈すればよいか. 応答この症例に㤬軽度の感音性難聴がある.CO 中 毒による内耳病変は否定できるが，他の原因による内 耳障害の可能性があり，それらが，聴性脳幹反応の潜 時延長に関与しているかもしれない.

\section{4. 実験的中耳炎における中耳粘膜血管透過性}

\section{に関する形態学的, 生化学的研究}

\author{
阪上雅史・松永 亨（阪大） Teruhiko Harada・Steven K. Juhn・Arndt J. Duvall（ミネソタ大）
}

目的 (1) 形態学的にトレーサーを用いて,正常及び 実験的中耳炎における中耳粘膜血管透過性を検討す る. (2) 中耳貯留液 (MEE) の組成を生化学的に分析す ろ.(3) 形態学的所見と生化学的所見の関連性を娭討す る.

方法 25匹のチンチラを 3 群に分けた.(i)コントロ 一ル群 (5匹): 正常チンチラに horseradish peroxidase (HRP) を投与した. (ii) 洷出性中耳炎 (SOM) 群 $(10$ 匹) : SOM は, 軟口蓋を切開し耳管にスポンジ
を詰めて作製した.耳管閉塞後 1 日目に 5 匹，1週間 目に 5 匹用いた。.MEEの細菌培責はすべて陰性であ った. (iii) 化膿性中耳炎 (POM) 群 (10匹): POM 住, 中耳腔に肺炎球菌 7F 型を接種して作製した。接種後 1 日目に 5 匹, 1 週間目に 5 匹用いた. 形態学的には, $\mathrm{HRP} 60 \mathrm{mg} / \mathrm{kg}$ を静注し, 10 分後中耳粘膜を固定した。 Graham and Karnovsky (1966) に準じて HRP 反応 させ, 以下常法に従って光䫓，電䫓標本を作製した。 生化学的には，中耳炎作製後 1 週間目に MEE と血液 